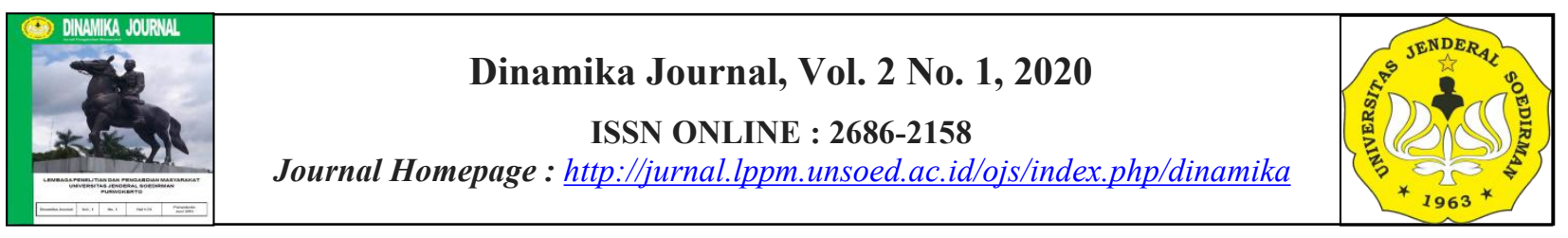

\title{
PEMBERDAYAAN MASYARAKAT DI DESA WLAHAR WETAN KECAMATAN KALIBAGOR KABUPATEN BANYUMAS GUNA MENCAPAI DESA MANDIRI SEJAHTERA
}

\section{Agus Sutanto $^{1 *}$, Anisur Rosyad ${ }^{1}$, Mujiono', Totok Agung Dwi Haryanto', Karseno", Akhmad Rizqul Karim ${ }^{1}$, Dyah Susanti ${ }^{1}$}

\author{
${ }^{1}$ Fakultas Pertanian, Universitas Jenderal Soedirman, Indonesia \\ *Corresponding author : tantoagus25@gmail.com
}

Received 20 December 2019; Accepted 1 February 2020; Available online 29 February 2019

\begin{abstract}
Abstrak
Pada tahun 2020 desa Wlahar Wetan ingin mencanangkan visinya menjadi Desa Pertanian Terpadu (Integrated Farming) dengan harapan kedepan menjadi desa Integrated Farming System atau sistem pertanian terpadu, yang merupakan penggabungan semua komponen pertanian yang meliputi pertanian, peternakan dan perikanan dalam suatu sistem usaha pertanian yang terpadu. Sistem ini mengedepankan ekonomi yang berbasis teknologi ramah lingkungan dan optimalisasi semua sumber energi yangdihasilkan. Untuk mencapai visi tersebut Tim Pengabdian pada tahun kedua ini telah melakukan kegiatan sebagaimana berikut: Pemetaan dan pendampingan komersialisasi produk unggulan (gropak, mino, dan kacang goreng), Pengembangan wisata berbasis agroteknologi berupa penanaman tanaman bunga dan kelapa, Peningkatan daya dukung lingkungan dalam produksi pangan dan hortikultura dengan penyediaan pompa air berbasis solar cell, yang menyedot air dari Sungai Serayu, Kegiatan pendayagunaan embung sebagai pusat agrowisata dialihkan ke BumiTambangan sebagai pusat agrowisata dan Peningkatan keaktifan kelompok tani padi organik dan hortikultura sebagai uapaya pemberdayaan masyarakat melalui kegiatan kunjungan lapang dan pelatihan pembuatan pupuk dan pestisida organik, serta teknik budidaya organik.
\end{abstract}

Kata kunci: Pemberdayaan, pendampingan, sistem pertanian terpadu

\section{Abstract}

In 2020 the village of Wlahar Wetan wants to launch its vision to become an Integrated Farming Village in the hope of becoming an Integrated Farming System or integrated farming system, which is a merger of all agricultural components including agriculture, animal husbandry and fisheries in an integrated farming business system. This system puts forward an economy based on environmentally friendly technology and optimization of all energy sources produced. To achieve this vision, the Community Service Team has carried out activities as follows below: Mapping and mentoring of commercialization of superior 
products (gropak, mino, and hot beans), Development of agrotechnology-based tourism in the form of planting flowers and coconut plants, Increasing the carrying capacity of the environment in food and horticultural production by providing solar cell-based water pumps, which suck water from the Serayu River, Empowerment of embung activities as an agrotourism center is transferred to BumiTambangan as an agro-tourism center and Increasing the activeness of organic rice and horticultural farmer groups as a means of community empowerment through field visits and training in making organic fertilizers and pesticides, and organic cultivation techniques.

Keywords : Empowerment, assistance, integrated farming systems

\section{PENDAHULUAN}

Desa Wlahar adalah salah satu desa yang terletak di Kecamatan Kalibagor Kabupaten Banyumas. Visi Desa Wlahar Wetan adalah: Menuju Pemerintah Desa Wlahar Wetan yang mampu menyelenggarakan pelayanan cepat dan prima dalam mendukung terwujudnya Wlahar Wetan yang sejahtera dan berbudaya menuju kemandirian kelembagaan kemasyarakatan desa serta tercapaianya pemerintah yang baik dan pemerintah yangbersih.

Pada tahun 2020 desa Wlahar Wetan ingin mencanangkan menjadi Desa Pertanian Terpadu (Integrated Farming) dengan harapan kedepan menjadi desa Integrated Farming System atau sistem pertanian terpadu, yang merupakan penggabungan semua komponen pertanian yang meliputi pertanian, peternakan dan perikanan dalam suatu sistem usaha pertanian yang terpadu. Sistem ini mengedepankan ekonomi yang berbasis teknologi ramah lingkungan dan optimalisasi semua sumber energi yangdihasilkan.

Untuk mencapai visi DesaWlahar Wetan, maka beberapa masalah. dan hasil diskusi antara tim pengusul dengan pihak pemerintah desa dapat diidentifikasi permasalahan sebagai berikut di bawah ini.

1. Rendahnya keberdayaan masyarakat dan kemampuan desa

2. Masih rendahnya tingkat pendidikanmasyarakat

3. Rendahnya tingkat ekonomimasyarakat

4. Rendahnya derajat kesehatan dan tingkat kesejahteraanmasyarakat

5. Adanya kerusakan sumber daya alam dan sumber daya air

Melalui program kegiatan PKM Bina Desa Mandiri Unsoed 2017-2019 ini, beberapa permasalahan di atas akan dipecahkan bersama-sama dengan melibatkan masyarakat, pemerintah desa, dinas terkait dan mitra pemasaran.

Kegiatan yang sudah dilakukan pada tahun 2017 (tahun pertama) meliputi: (1) pembibitan padi menggunakan benih Inpago 1 Unsoed untuk 7 ha; (2) penanaman padi sistem organik seluas $2 \mathrm{ha}$, dan 5 ha masih menggunakan pupukanorganik; (3)pembuatan danaplikasi pupuk organic dan pestisida organik untuk 2 ha lahan padi sistem organik; dan (4) pelatihan-pelatihan dan pendampingan kegiatan penyemaian benih, pengolahan lahan seluas 7 ha, penanaman, pemeliharaan serta pemanenan padi yang akan dilakukan awal bulan Februari 2018.

Rencana kegiatan tahun kedua adalah sebagai berikut: (1) pemetaan dan pendampingan komersialisasi produk unggulan, (2) pengembangan wisata berbasis agroekologi, (3) peningkatan daya dukung lingkungan dalam produksi pangan dan hortikultura (4) pendayagunaan embung sebagai pusat agroekowisata, serta (5) peningkatan keaktifan kelompok tani padi organik dan hortikultura organk. 


\section{METODE PELAKSANAAN}

Pengandian kepada masyarakat dilaksanakan di Desa Wlahar Wetan Kecamatan Kalibagor Kabupaten Bnyumas. Pengabdian kepada masyarakat ini dilakukan dengan metode survei, pendampingan, pelatihan, dan pemberdayaan masyarakat. Kelompok sasaran meliputi: a. Kelompok perajin makanan meliputi: perajin gropak (15 orang), perajin mino, perajin kacang goreng.

b. Kelompok petani hortikultura (20 orang)

Pendampingan dilakukan terhadap para perajin makanan untuk memperoleh pasar yang lebih luas. Implementasi teknologi tepat guna berupa pemanfaatan energy solar cell untuk memberdayakan masyarakat dalam pemanfatan air serayu untuk pengairan tanaman hortikultura, khususnya pada musim kemarau.

\section{HASIL DAN PEMBAHASAN}

\section{A. PELAKSANAAN BINA DESA}

1. Pemetaan dan pendampingan komersialisasi produk unggulan

Kegiatan ini meliputi beberapa sub kegiatan sebagai berikut ini.

a. Kegiatan pemetaan produk unggulan

Dari kegiatan ini teridentifikasi beberapa produk industry rumah tangga unggulan yang perlu pengembangan, yaitu indutri gropak singkong, mino, dan kacang tanah goreng.

b. Pendampingan unit usaha terpilih

Dari produk unggulan yang terpetakan, terpilih untuk segera memperoleh pendampingan adalah industry gropak singkong. Langkah awal pendampingan, yaitu memperbaiki tempat pembuatan gropak, yang meliputi renovasi tungku menjadi tungku bersih.

c. Pendampingan unit usaha

Langkah pendampingan berikutnya adalah curah masalah dan pendapat (semacam Forum Group Discussion= FGD).
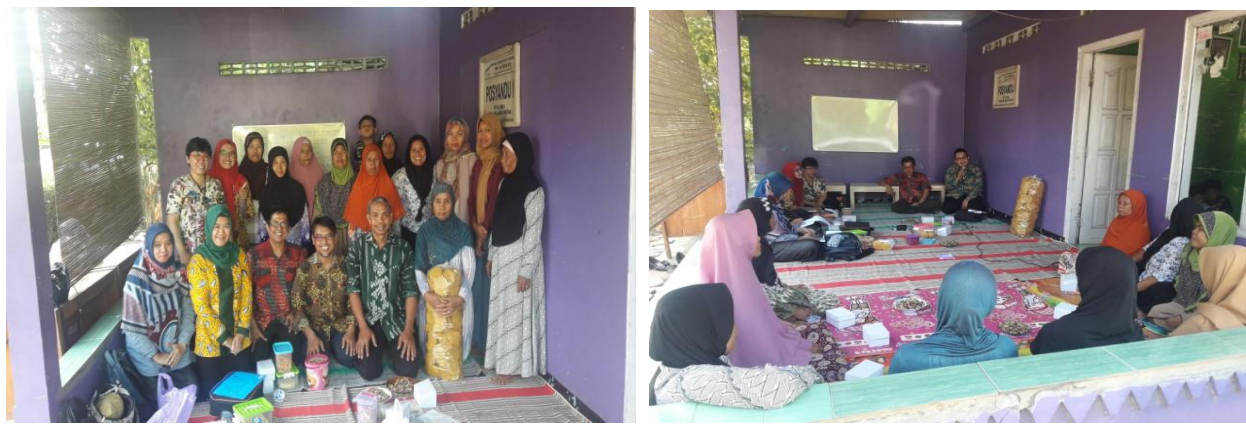

Dari hasil diskusi (seperti FGD), diperoleh beberapa catatan:

1) Keunggulan
a) Aspek penguasaan teknologi pengolahan sdh cukup baik (sudah berjalan cukup lama)
b) Mutu produk sudah baik (tekstur, rasa dll)
c) Lokasi perajin pada area yg sama, shgg dpt menjadi sentra
d) Komitmen perajin utk usaha gropak cukup kuat.

2) Kelemahan

a) Belum ada kelompok 
b) Ketergantungan bahan baku dan fluktuasi harganya

c) Harga produk dibeli murah (tdk ada daya tawar)

d) Pemasaran terbatas (diambil pengepul)

e) Penjualan bentuk curah $(@ 5 \mathrm{~kg})$

f) Ukuran produk beragam (besar, kecil)

g) Mutu antar perajin bervariasi

h) Ada variasi kemasan @ 0.5 kg,yang masih sederhana

i) Ketergantungan sinar matahari utk pengeringannya

j) Sanitasi ruang produksi masih sangat rendah (GMP belum berjalan)

3) Langkah selanjutnya yang dapat/akan diagendakan (perlu)
a) Perbaikan/standarisai ukuran (perbaikan cetakan)
b) Perbaikan kemasan
c) Jejaring pemasaran dg harga yg lebih baik (pak Jiemy siap membantu pemasaran)
d) Perbaikan beberapa peralatan agar standar (tatakan, cetakan, dll)

4) Jangka panjang berikutnya
a) Pembentukan kelompok dan pengelolaannya (kelembagaan)
b) Alat pengering (oven) agar tdk tergantung cuaca
c) Perbaikan dapur produksi (dapur sehat) spy lebih hyigienis
d) Pengurusan PIRT produk
e) Model pemasaran yg lebih luas

2. Penguatan sistem pertanian organik

Program ini dilakukan dengan sub kegiatan berikut di bawah ini.

a. Kunjungan lapang

Kunjungan lapang dengan cara membawa petani ke lahan budidaya hortikultura oranik di Desa kawangwuni, Kecamatan Sumbang. Dalam kunjungan tersebut petani Wlahar Wetan melakukan kegiatan melihat dan bertanya teknik budidaya organik. Pelaksanaan kunjungan lapang dilaksanakan pada Selasa, 10 September 2019.

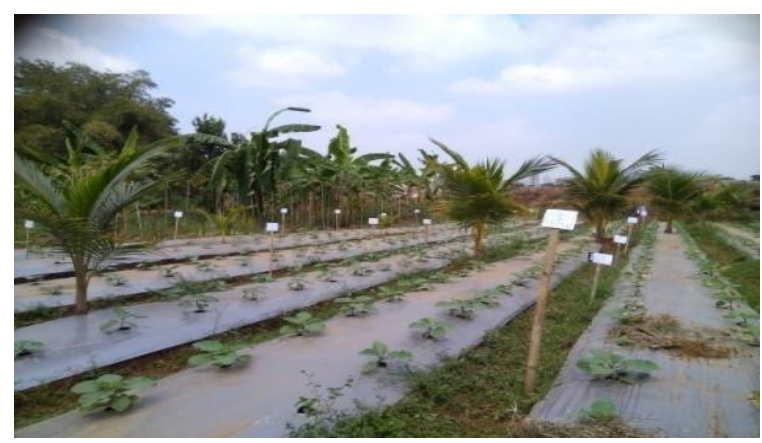

b. Pelatihan pembuatan pupuk dan pestisida nabati

Pelatihan ini dilaksanakan pada Hari Selasa, 10 September 2019 di Desa Bantarwuni, Kecamatan Kembaran, Kabupaten Banyumas, Jawa Tengah. 

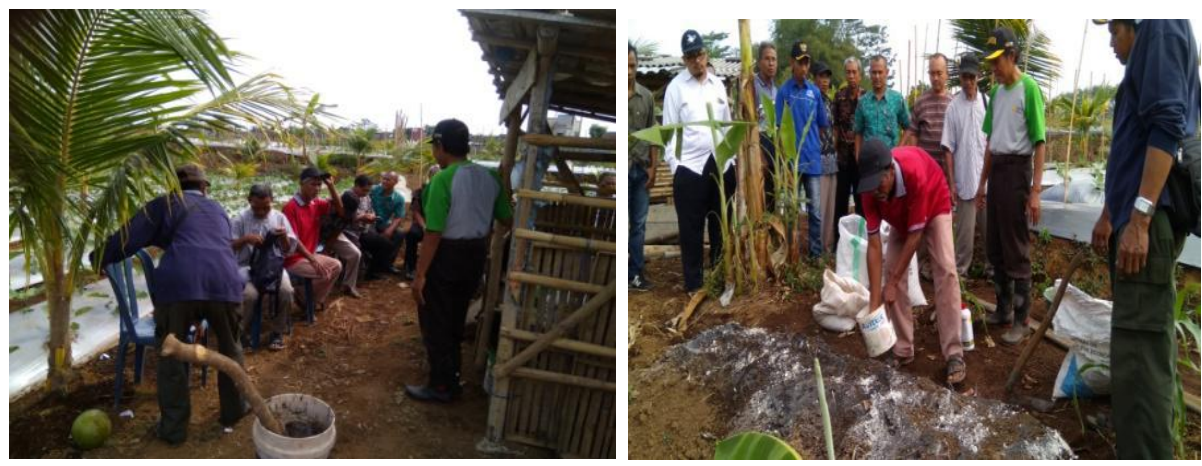

\section{Isi kegiatan}

1) Pembelajaran tentang pestisida nabati dan phospat nabati.

Pestisida nabati dapat berfungsi sebagai pengusir, pengurang nafsu makan dan pembunuh hama tanaman. Pestisida nabati memiliki keunggulan, tetapi juga memiliki kekurangan.

Kelebihan pestisida nabati, meliputi:

a) Bahan mudah didapat dan proses pembuatannya mudah.

b) Murah.

c) Penguraian cepat oleh matahari.

d) Dapat mengurangi risiko terjadinya resisten, resurjensi dan letusan hama sekunder.

e) Relatif aman terhadap musuh alami, mengurangi bahaya terhadap kesehatan manusia dan ternak.

f) Dapat dipadukan teknik pengendalian yang lain dan juga dapat dicampurkan dengan OC daun (seperti SO-Kontan Fert).

g) Mudah terurai di lingkunan (bersifat tak persisten), sehingga bersifat ramah lingkungan.

h) Keberlanjutan pertanian terjaga.

Kekurangan pestisida nabati, meliputi:

a) Daya racunnya rendah.

b) Hasilnya tidak cepat terlihat nyata.

c) Relatif sulit diproduksi dalam skalai besar.

d) Umumnya tidak dapat tahan lama disimpan.

e) Sukar larut dalam air karena bersifat tak polar, dan kesulitan menentukan dosis dan kandungan kadar bahan aktif dalam bahan nabati.

f) Memerlukan frekwensi aplikasi yang lebih banyak, sehingga mengurangi aspek kepraktisan serta diperlukan bahan tumbuhan yang lebih banyak untuk mencapai keefektifan yang memadai.

Solusi untuk mengatasi kelemahan tersebut,antara lain, yaitu:

a) Dalam aplikasinya digabung/dicampur dengan POC daun (seperti SO-Kontan Fert), sehingga dapat beperan ganda.

b) Waktu aplikasi harus tepat, yaitu pada saat populasi/intensitas serangan OPT masih rendah.

c) Khusus untuk pengendalian hama walang sangit, berdasarkan pengalaman, maka waktu aplikasi pestisida maja gadung yang paling tepat adalah pada saat tanaman padi memasuki fase bunting (malai belum muncul), yaitu dengan aplikasi 5 kali, yaitu 3 kali pada minggu pertama dan 2 kali pada minggu berikutnya. 
d) Frekuensi aplikasi ditambah misalnya dua kali seminggu.

2) Cara membuat pestisida nabati buah maja dan umbi gadung.

a) Bahan baku yang digunakan adalah buah maja (10 buah) dan umbi gadung (3 kg), air (10 lt), telur ayam (3 buah).

b) Buah maja dibelah, daging buahnya diambil dan dimasukkan kedalam ember plastik, kemudian ditambah perasan $3 \mathrm{~kg}$ parutan umbi gadung.

c) Selanjutnya dihancurkan sampai halus.

d) Kedalam campuran tersebut dimasukkan 3 butir telur ayam atau 2 butir telur bebek dan 10 lt air, kemudian diaduk hingga homogen.

e) Ember ditutup rapat dan difermentasikan selama 14 hari.

f) Setelah 14 hari, disaring dan siap diplikasikan.

g) Jika ingin disimpan, maka dapat dimasukkan ke dalam jeligen, ditutup rapat, dan dapat disimpan selama 2-3 tahun pada kondisi suhu kamar.

h) Jika akan digunakan disarankan ditambah rebusan bahan pestisida nabati lain, seperti tembakau (konsentrasi 2 ons/3 lt) atau gerusan cabai dan bawang putih secukupnya.

3) Cara membuat fosfat nabati

Langkah-langkah dalam pembuatan fosfat nabati, yaitu meliputi:

a) Masukkan nira kelapa segar atau yang rusak ke dalam ember bekas cat sebanyak 4-5 liter.

b) Masukan irisan tipis hati batang pisang ke dalam ember tersebut dan kemudian tutup rapat (difermentasi).

c) Setelah 2 minggu disaring dan siap diaplikasikan melalui daun.

d) Dalam aplikasinya dapat dicampurkan dengan POC daun (seperti SO-Kontan Fert) konsentrasi $6 \%$ dan diusahakan diaplikasikan pada saat padi memasuki fase bunting (umur 45-55 hari setelah tanam).

4) Cara perbanyakan jamur Trichoderma sp. dengan medium cair.

Bahan:

4 gelas air cucian beras

1 gelas air kelapa

1 sendok makan gula pasir

Cara pembuatan:

a) Satukan semua bahan menjadi satu dalam satu panci, dan rebus sampai mendidih.

b) Siapkan jerigen bersih, dan masukkan dengan disaring air rebusan cucian beras yang di tambahkan air kelapa.

c) Biarkan medium air cucian beras dan air kelapa tersebut dingin. Pendinginan dapat dipercepat dengan merendam jerigen dalam ember yang berisi air dingin.

d) Setelah dingin masukkan biakan jamur Trichoderma sp. ke dalam medium air cucian beras dan air kelapa, dan dilakukan pengocokan.

e) Biarkan medium hingga 7 hari pada suhu ruang, dan jangan terkena sinar matahari secara langsung, dan dalam setiap harinya dilakukan pengocokan 2-3 kali sehari.

c. Peningkatan daya dukung lingkungan bagi produksipertanian

1) Menaikan air dengan hidram. Teknologi ini tidak dapat dilakukan karena tidak diperoleh perbedaan ketinggian air dalam sungai. Sungai Serayu berada relative 
datar.

2) Menaikan air dengan kincir angin. Teknologi inipun tidak dapat dilaksanakan karena kecepatan angin tidak stabil.

3) Menaikan air dengan pompa air dengan energi "solar cell". Teknologi inilah yangdipilih. Tim telah menggunakan teknologi solar cell ini dan hasilnya telah dimanfaatkan oleh masyarakat.
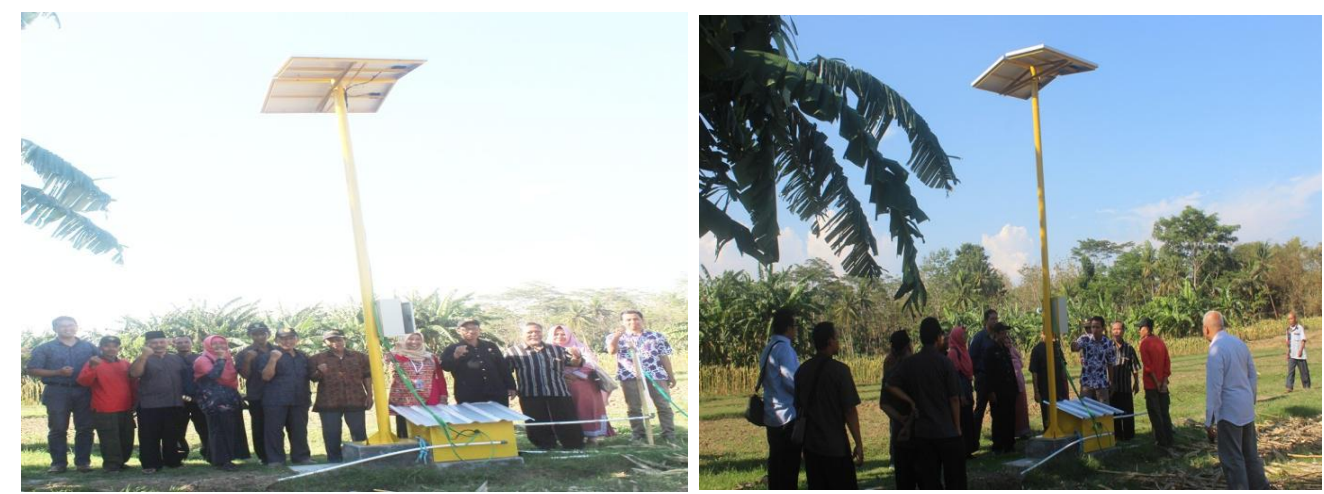

d. Pendayagunaan Bumi Tambangan sebagai pusatagroekowisata

Kegiatan yang dilakukan adalah mendukung pengembangan Bumi Tambangan sebagai pusat agrowisata berbasis ekologi. Bentuk kegiatan meliputi penanaman bunga dan tanaman kelapa sepanjang jalan di lokasi Bumi Tambangan. Bahan berupa tanaman bunga dan tanaman pohon kelapa telah ditanam.

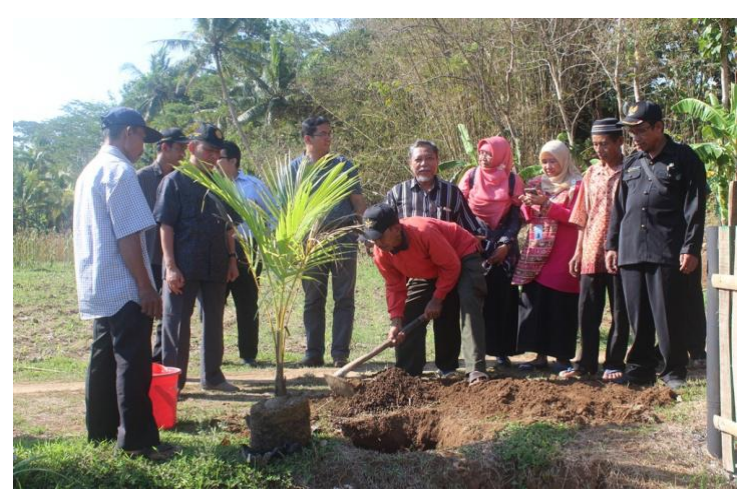

e. Penguatan kelembagaan kelompok tani pertanian organik (manajemen, marketing) Bentuk kegiatan ini curah pendapat dengan para angggota kelompok tani. Kegiatan ini akan dilaksanakan bersama dengan kegiatan penanaman bunga dan tanaman pohon kelapa serta peresmian penggunaan pompa air berbasis solar cell.

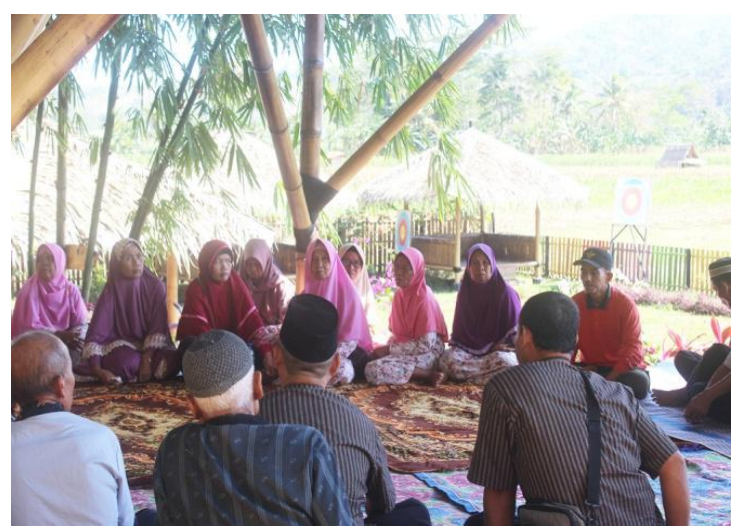




\section{KESIMPULAN}

Kegiatan bina desa telah berjalan dengan baik. Telah diperoleh peta produk unggulan yang meliputi produk gropak, mino, dan kacang goreng. Perajin didampingi dalam proses produksi, dengan peningkatan efisiensi dan peningkatan kesehatan proses produksi dengan pembuatan tungku bersih. Forum Group Discusion dilakukan untuk curah pendapat para perajin makanan untuk memperluas pasar.

Para petani padi dan hortikultura telah dilatih untuk melakukan budidaya secara organiK, dan membuat pupuk dan pestisida organik.

Untuk mengatasi kekurangan air untuk proses produksi pertanian telah diimplementasin teknologi solar cell untuk mengangkat air dari Sungai Serayu. Untuk meningkatkan kualitas tempat wisata Bumi Tambangan, telah diperindah dengan penanaman bunga dan tanaman kelapa.

\section{UCAPAN TERIMA KASIH}

Atas terselenggaranya bina desa ini, maka tim menyampaikan terima kasih kepada Pimpinan Universitas Jenderal Soedirman, dalam hal ini Ketua LPPM Unsoed yang telah mendanai kegiatan ini dan Dekan Fakultas Pertanian yang telah melancarkan proses kegiatan bina desa ini.

\section{DAFTAR PUSTAKA}

Allidawati dan Bambang K. 1993. Metode Uji Mutu Beras dalam Program Pemuliaan Padi. Dalam Padi. Hal. 363-375. Badan Penelitian dan Pengembangan Pertanian. Pusat Penelitian dan Pengembangan Tanaman Pangan. Bogor.

Damardjati. D.S. 1997. Masalah dan Upaya Peningkatan Kualitas Beras Ditinjau Dari

Aspek Pra dan Pasca Panen Dalam Menghadapi Era Globalisasi. Makalah Seminar Pasca Panen. Peningkatan Kualitas dan Pelayanan masyarakat. Jakarta. 6 Mei 1997.

Darajat, A.A. dan M.Y. Samaullah. 1998. Toleransi beberapa genotype padi sawah terhadap cekaman kekeringan. Zuriat: IX:45-49.

Deptan. 2008. Basis Data Pertanian. Departemen Pertanian. http://database.deptan.go.id /bdspweb/bdsp2007/hasil_kom.asp. diakses tanggal 4 Maret 2008.

Deva, N. 1996. Strees tolerance in crops plant. In. Beyrouty, C.A. and F.D. Bueno (Ed). Proceeding of international conference on stress physiology of rice 28 February - 5 March 1994. IRRI Philippines. p: 123-145.

Ishaq, I. 2009. Petunjuk Teknis Penangkaran Benih Padi. Balai Pengkajian Teknologi Pertanian (BPTP) Jawa Barat, Badan Penelitian dan Pengembangan Pertanian, Departemen Pertanian

Menteri Pertanian. 2011. Keputusan Menteri Pertanian tentang Pelepasan Galur Padi Gogo Unsoed G10 sebagai Varietas Unggul Dengan Nama Inpago Unsoed 1. Kementerian Pertanian, Jakarta.

Pemerintah Desa Wlahar Wetan. 2015. Profil Desa Wlahar Wetan. Pemerintah Desa Wlahar Wetan, Kecamatan Kalibagor Kabupaten Banyumas

Pracaya. 2002. Bertanam Sayuran Organik. Jakarta: PT. Penebar Swadaya. 
Suprihatno, B. 2010. Deskripsi Varietas Padi. Balai Besar Penelitian Tanaman Padi, Sukamandi.

Totok A.D.H., Suwarto, L. Soesanto, Daryanto. 2003. Perakitan Varietas Padi Gogo Berdaya Hasil Tinggi dan Aromatik untuk Meningkatkan Produksi dan Nilai Ekonomi Padi Gogo. Laporan Penelitian Hibah Bersaing. Fakultas Pertanian Unsoed. Purwokerto.

Totok ADH. 2008. "Mutiara Yang Terlupakan" (Upaya Peningkatan Ketahanan Pangan Melalui Pengembangan Padi Gogo Aromatik). Orasi Ilmiah Pengukuhan Guru Besar Universitas Jenderal Soedirman Purwokerto. 